\title{
Coating based on breadfruit starch (Artocarpus altilis) for fruit conservation: influence of glycerol, sorbitol, and mannitol as plasticizers
}

\author{
Erick dos Anjos BEZERRA ${ }^{1 \star}$, Edilayane da Nóbrega SANTOS ${ }^{1}$, Natália Silva de FARIAS ${ }^{2}$, \\ Mônica Tejo CAVALCANTI ${ }^{1}$ (D)
}

\begin{abstract}
Polysaccharide-based coatings are an alternative to synthetic coatings for fruit conservation. In this study, we aim to evaluate the physical and chemical characteristics of breadfruit starch for coating using glycerol, sorbitol, and mannitol as plasticizers. We applied coatings composed of $7 \%$ starch and $2 \%$ plasticizers to cherry tomatoes, and evaluated the storage during 12 days at a temperature of $18^{\circ} \mathrm{C}$. The breadfruit starch had an amylose content of $27.17 \%$, granular size of $0.85-0.87$, a gelatinization temperature of $75.10^{\circ} \mathrm{C}$, characteristics of standard starch type B and low syneresis. Coatings composed of glycerol and sorbitol showed a reduction in mass loss and delayed ripening. Glycerol and sorbitol are recommended for preparing coatings based on breadfruit starch for post-harvest storage of tomatoes.
\end{abstract}

Keywords: CATA; cherry tomato; post-harvest; sensory evaluation.

Practical Application: Diversify the use of starch as a new technology in the food industry.

\section{Introduction}

There is a need to replace synthetic products as plastic coatings based on petrochemical materials with coatings based on natural products that are renewable or biodegradable for improving storage of plant products like fruits. The use of natural products as material for coating may decrease production costs, as well as being abundant in nature and renewable. Coatings based on polysaccharides are a versatile alternative to applications in the food industry, not just aiming to improve food conservation (Falcão-Rodrigues et al., 2007; Cazón et al., 2017; Nawab et al., 2017), but also to produce an environmentally friendly product.

Starch is a highly demanded product in the food industry due to its low price, abundance, and versatility. Non-conventional starches may supply part of the demand (Nawab et al., 2017), such as breadfruit starch (Artocarpus altilis). Breadfruit is a tropical fruit from Malaysia, South Pacific, and the Caribbean from the Moraceae family (Nwokocha \& Williams, 2011; Turi et al., 2015) containing from 18 to $37 \mathrm{~g} / 100 \mathrm{~g}$ of carbohydrates in its composition. The amylose and amylopectin contents vary from 16.4 to $53.7 \%$ and 72.3 to $77.5 \%$, respectively, the granular size from 0.5 to $37.8 \mu \mathrm{m}$, a gelatinization temperature of $69.3{ }^{\circ} \mathrm{C}$ and crystallinity of $14.3 \%$ (Turi et al., 2015; Tan et al., 2017).

Cherry tomato (Solanum lycopersicum var. cerasiforme) is a suitable fruit for testing coatings. Cherry tomato is a fruit that is consumed all over the world, is rich in vitamin C, flavonoids and $\beta$-carotene (Wu et al., 2016). However, cherry tomatoes are seasonal and highly perishable due to transpiration, needing storage technologies to maintain their physiological, physical, chemical and biochemical characteristics (Fagundes et al.,
2015; Nawab et al., 2017). Studies on tomato conservation (Fagundes et al., 2014, 2015; Badawy \& Rabea, 2009; Ali et al., 2010, 2013; Beckles, 2012; Nawab et al., 2017) indicate that coatings with new ingredients may be tested in the preservation of texture and nutritional value of the fruit.

Therefore, this study evaluated the characteristics of starch made from breadfruit (Artocarpus altilis) and its efficiency when associated with plasticizers such as glycerol, sorbitol and mannitol as a coating for cherry tomato (Solanum lycopersicum var. cerasiforme).

\section{Materials and methods}

We used breadfruit (Artocarpus altilis) as raw material from the apyrena variety. We collected the breadfruits in the Santa Rita region, Paraíba, Brazil. Breadfruit was harvested in an unripe state and analyzed at the Laboratory of Grain and Cereals of Federal University of Campina Grande (UFCG).

The cherry tomatoes (Solanum lycopersicum var. cerasiforme) were sampled according to size, aspect, and color. Tomatoes with a predominantly reddish color in the peel, free from damage and fungi were used in this study.

\subsection{Starch extraction}

The starch was extracted following the method described by Adebowale et al. (2006), using the insolubility principle. The breadfruits were peeled, cut into cubes and immersed in

${ }^{1}$ Unidade Acadêmica de Tecnologia de Alimentos, Centro de Ciências e Tecnologia Agroalimentar, Universidade Federal de Campina Grande - UFCG, Pombal, PB, Brasil

${ }^{2}$ Programa de Pós-graduação em Ciência dos Alimentos, Centro de Ciências Agrárias, Universidade Federal de Santa Catarina - UFSC, Florianópolis, SC, Brasil

*Corresponding author: erickdosanjos@gmail.com 
sodium bisulfite solution (1\%) for 24 hours to avoid enzymatic darkness. After, the fruits were triturated in an industrial blender (Brand Urano, UCB 950F, Rio Grande do Sul, Brasil) for 40 seconds. The resulting change from mass precipitate was filtered through a sieve of 200 mesh size. The residue in the sieve was washed with $2000 \mathrm{~mL}$ of distilled water. The decanted masses put in a drying oven Solab (SL 102/150, Piracicaba, Brazil) at a temperature of $40{ }^{\circ} \mathrm{C}$ until 12 to $13 \%$ of moisture as recommended by Chiang et al. (1987). The starch yield was calculated on a dry basis from the initial mass of the fruit used, as determined by Equation 1.

$$
\text { Yield }(\%)=\frac{\text { dry starch weight }(\mathrm{g})}{\text { weight of initial mass }(\mathrm{g})} \times 100
$$

\subsection{Physical-chemical parameters}

We evaluated the moisture, protein ( $\mathrm{N}$ x 6.25), lipid and ash content from the breadfruit in nature and the starch, using the methods 44-15.02, 46-13.01, 30-20.01 and 08-01.01 (American Association Cereal Chemists, 2010), respectively. The total starch content was determined using the Antrona method (Labanca et al., 1999). Amylose content was determined following the method described by Martínez et al. (1989).

\subsection{Scanning Electron Microscopy (SEM)}

The morphology evaluation of the starch granule was performed using a Scanning Electron Microscope (SEM) with micrographs obtained under a JEOL Ltd. microscope (5800LV, Akishima, Japan) under a voltage of $3 \mathrm{kV}$. We used a working distance (WD) of $13 \mathrm{~mm}$ and increases of 2000x to 5000x in the Laboratory of Electron Microscopy of the Physics Department of the Federal University of São Carlos (UFSCar).

\section{$2.4 X$-ray diffraction}

$\mathrm{X}$-ray diffractograms of the starch were obtained in a Rigaku $\mathrm{X}$-ray Diffractometer-Rigaku Corporation diffractometer (Miniflex, Osaka, Japan) operated at $(30 \mathrm{kV}, 15 \mathrm{~mA})$, with a 0.05 pitch and scanning rate of $1 \% \mathrm{~min}$ at room temperature. The diffraction scanning range was adjusted to angles of $5^{\circ} \leq 2(\theta) \leq 60^{\circ}$

\subsection{Water absorption capacity}

The water absorption capacity (WAC $\mathrm{g}_{\text {water }} / \mathrm{g}_{\text {starch }}$ ) of the breadfruit starch was performed by the method of Beuchat (1977).

\subsection{Gelling and starch paste characteristics}

The gelling capacity was analyzed according to the method described by Lawal \& Adebowale (2005). The starch paste properties were evaluated in the Rapid Visco Analyzer-Perten Instruments Rapid Viscosity Analyzer, (RVA 4500, Huddinge, Sweden). The viscosity profile was determined using Standard 1 heating program (the sample was held at $50{ }^{\circ} \mathrm{C}$ for 1 minute, heated to $95{ }^{\circ} \mathrm{C}$ for 3.75 minutes and kept at this temperature for 2.50 minutes, cooled to $50{ }^{\circ} \mathrm{C}$ for 3.75 minutes and held at this temperature for 2 minutes, lasting a total of 12 minutes). The evaluated parameters were pulp temperature $\left({ }^{\circ} \mathrm{C}\right)$, maximum viscosity (Cp), peak time and tendency to retrograde (Cp). The measurements were performed in triplicate.

\subsection{Paste clarity}

To determine the clarity of the paste, the sample absorbance was measured in a Biospectro ${ }^{\circledR}$ digital spectrophotometer (SP 220, Curitiba, Brazil), in the visible light interval at $640 \mathrm{~nm}$, during the periods of 24, 48, 72 and 120 hours (Singh et al., 2004).

\subsection{Syneresis}

Syneresis was determined as the concentration in which the sample did not previously slip through the tube in the gel analysis. The samples were stored at $4{ }^{\circ} \mathrm{C}$ for $24,48,72,120$ and $360 \mathrm{~h}$. Syneresis was measured as the percentage (\%) of water released after centrifugation of the samples in a Cientec ${ }^{\circledR}$ centrifuge (CT-5000R, Belo Horizonte, Brazil) at 1500 x G for 15 minutes (Singh et al., 2004).

\subsection{Preparation of the starch-based breadfruit coating}

The coatings were made with $7 \%(\mathrm{w} / \mathrm{v})$ breadfruit starch in distilled water where the solution was heated to $95{ }^{\circ} \mathrm{C}$ in a water bath for 5 minutes over manual stirring until complete dissolution. The plasticizing solutions of glycerol (C1), sorbitol (C2) and mannitol (C3) were added to the starch solution at the concentration of $2 \%(\mathrm{v} / \mathrm{v})$. The cherry tomatoes were immersed for 1 minute in the corresponding film-forming solution until natural drying at $25^{\circ} \mathrm{C}$. The samples were placed in polypropylene trays and stored in an incubation chamber by biochemical oxygen demand (BOD) in the chamber-NEWLAB (NL 161-01, Piracicaba, Brazil) at $18{ }^{\circ} \mathrm{C}$ with a relative humidity of $60-75 \%$ and evaluated at the $1^{\text {st }}, 3^{\text {rd }}, 6^{\text {th }}, 9^{\text {th }}$, and $12^{\text {th }}$ days of storage.

We tested three treatments with the plasticizing solutions of glycerol (C1), sorbitol (C2) and mannitol (C3), and a control without any coating in cherry tomatoes. In addition, shelf-life was monitored as described below.

\subsection{Characterization of cherry tomatoes}

The characteristics evaluated in the cherry tomatoes were mass loss, moisture, ash, $\mathrm{pH}$, titrated acidity, citric acid, ascorbic acid, total soluble solids, maturation index and water activity. The fruits were weighed in a semi-analytical Engineering scale (M163, Piracicaba, Brazil) with mass loss expressed in percentage (\%), calculated from the final and initial weight difference. Determination of the moisture and ash content was performed by the method proposed by the American Association Cereal Chemists (2010). Titrated acidity (TA), pH, percentage of citric acid, ascorbic acid and total soluble solids ( ${ }^{\circ} \mathrm{Brix}$ ) (TSS) were determined according to Methods no. 942.15, no. 981.12, no. 967.21 and no. 932.12, respectively (Association of Official Analytical Chemists, 2005). The maturation index was calculated using the TSS/TA ratio. Water activity (WA) was determined by direct measurement in a Decagon apparatus, Pulman-AquaLab (3TE, Washington, USA), adding the sample into the equipment compartment at a temperature of $25^{\circ} \mathrm{C}$. 


\subsection{Sensory evaluation of coated cherry tomatoes}

The coated tomatoes were sensorially evaluated for visual acceptability using a hedonic scale of 1 to 9 points, corresponding to 1 (I really disliked it) and 9 (I enjoyed it very much) (Dutcosky, 2013). The evaluation was performed with an inexperienced team of 60 people from different ages that make up the university community of the Federal University of Campina Grande (UFCG). The analysis was approved by the Ethics Committee on Research in Human Beings according to the National Health Council by Resolution No. 466 of December 12, 2012, of the CNS (Opinion No. 009738/2017).

The cherry tomatoes were visually observed by the judges in individual monotonic cabins arranged in glass plates, with standardized amounts (1 fruit per treatment evaluated), under controlled temperature and lighting conditions. The tomatoes were encoded with three digits. The purchase intention of consumers was evaluated through a purchase intention test using a 5-point verbal scale, with 1 corresponding to "I would certainly buy it" and 5 to "I would certainly not buy it".

The participants of this analysis answered the Check All That Apply (CATA) questionnaire containing sensorial attributes to describe the samples, according to the methodology described by Ares et al. (2010). The position of the terms in the questionnaire was balanced according to the adapted method recommended by Ares et al. (2014) to avoid tendency.

\subsection{Statistical analysis}

The mean results of three replicates were analyzed by Analysis of Variance (ANOVA) obtained by the mean and standard deviation. The means were submitted to the Tukey test, considering the level of probability of error (p) less than $5 \%$ to determine the significance. The data were analyzed through Assistat version 7.6 beta software (Universidade Federal de Campina Grande, 2014). Correspondence analysis was used to determine the association between CATA and hedonic answers. We used the R software for sensory analysis of the CATA (R Core Team, 2014).

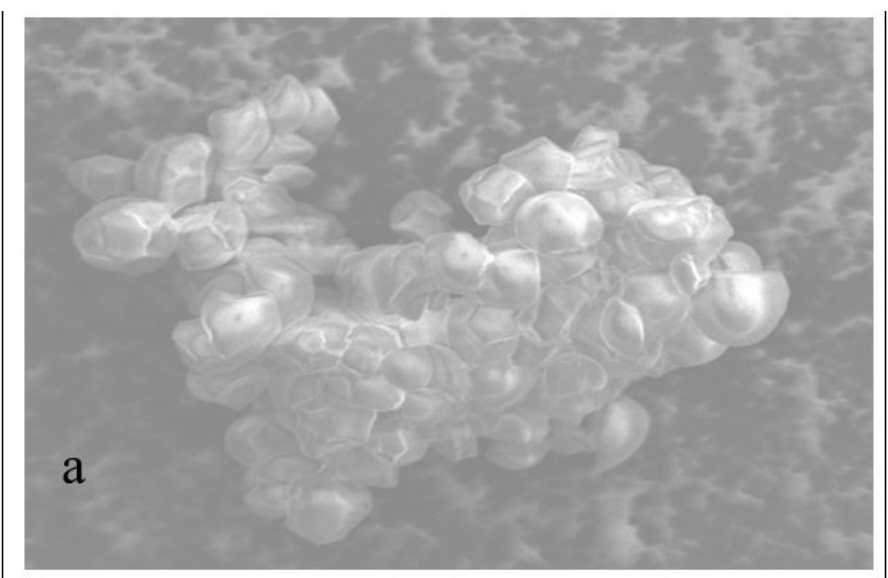

\section{Results and discussion}

The efficiency of starch extraction from breadfruit was $27.87 \%$ $(\mathrm{w} / \mathrm{w})$. This was a higher value than that reported by Nwokocha \& Williams (2011) of 14.30-18.50\%, and Ricón \& Padilla (2004) of $18.51 \%$. This difference can possibly be explained by the maturation degree, climatic conditions and seasonal effect of the fruit (Turi et al., 2015).

Breadfruit in natura showed a moisture content of $68.76 \%$ $( \pm 0.02)$, ash content of $0.61 \%( \pm 0.01)$, protein of $1.73 \%( \pm 0.01)$, lipid content of $0.55 \%( \pm 0.01)$, carbohydrates content of $17.2 \%$ and starch content of $24.68 \%$ (0.39). For Nacitas Latchoumia et al. (2014), the driest season is the best time to harvest the fruits, obtaining a higher concentration of carbohydrates and a sweeter flavor because the climatic conditions favor the accumulation of this macronutrient.

The obtained starch had a moisture content of $12.56 \%( \pm 0.05)$, with low contents of ashes $(0.33 \% \pm 0.01)$, lipids $(0.36 \% \pm 0.01)$ and proteins $(1.27 \% \pm 0.01)$. The obtained starch content was 83.97\%; a value similar to that found by Adebowale et al. (2005) of $84.48 \%$, indicating the efficiency of the method used for its extraction. The amylose content was $27.17 \%$. The differences may be related to the cultivars and/or the fruit harvest season (Akanbi et al., 2009; Ricón \& Padilla, 2004; Tumaalii \& Wootton, 1988; Wang et al., 2011; Wootton \& Tumaalii, 1984; Turi et al., 2015; Nwokocha \& Williams, 2011).

A predominantly spherical shape was observed with smooth surfaces and small aggregates in the morphology of starch granules (Figure 1a, b). The granules presented circularity ranging from $0.85-0.87 \mu \mathrm{m}$ and elongation factor (maximum diameter/minimum diameter) of 1.66. According to Rowney et al. (2003), samples with circularity equal to 1 indicate perfectly circular particles. A higher value (1.59) was found by Nwokocha \& Williams (2011) for breadfruit starch.

$\mathrm{X}$-ray diffraction of the starch, breadfruit starch (AFP) (Figure 2) indicates a standard type B starch, well-defined, intense and narrow peaks with diffraction in $2(\theta)$ of $5.6^{\circ}, 14.4^{\circ}, 17.2^{\circ}, 19^{\circ}, 22.2^{\circ}$ and $24.0^{\circ}$, common in tubers and fruit starches. Nwokocha \& Williams (2011) indicated the

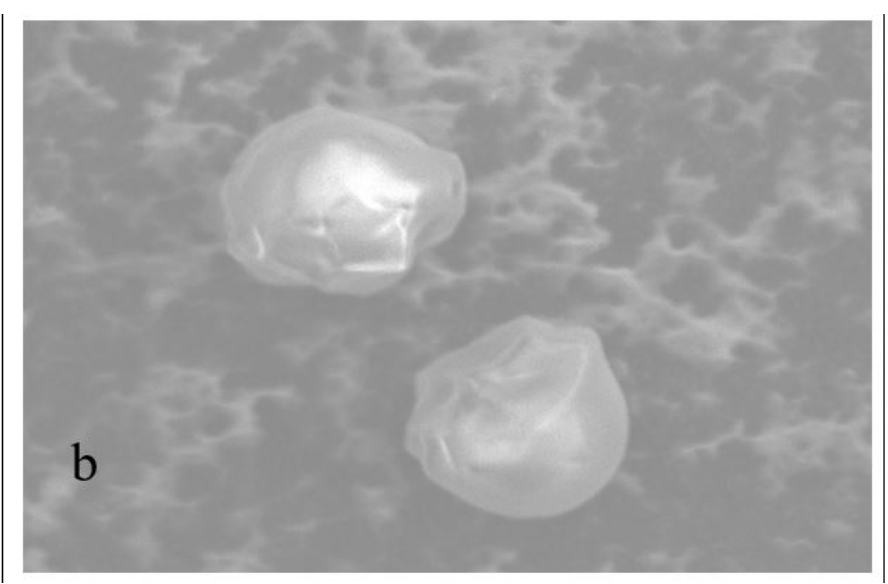

Figure 1. Micrographs of breadfruit starch observed under Scanning Electron Microscopy (increase: (a) 2000x; (b) 5000x). 


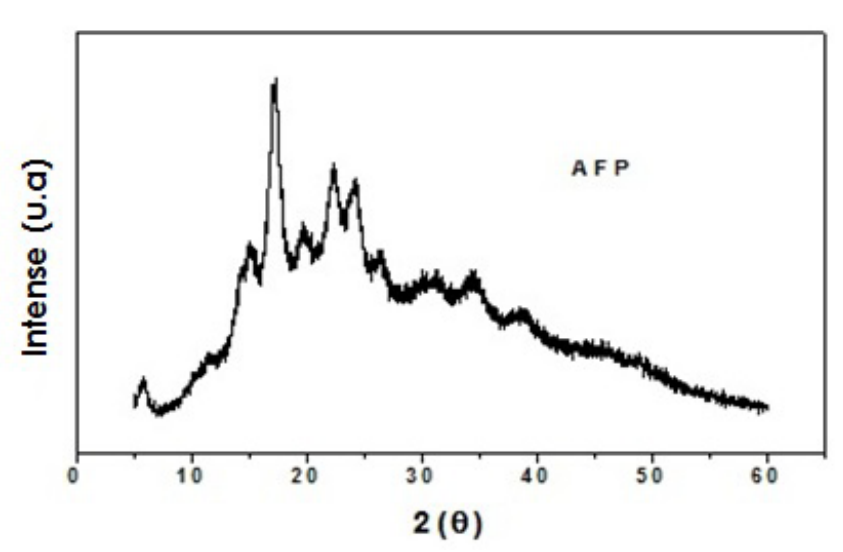

Figure 2. Breadfruit starch X-ray diffraction (BFS) breadfruit starch (AFP) curves.

breadfruit as type $\mathrm{B}$, finding diffraction peaks in $2(\theta)$ of $5.8^{\circ}$, $14.76^{\circ}, 15.3^{\circ}, 17.32^{\circ}, 19.88^{\circ}, 22.92^{\circ}$ and $23.88^{\circ}$. The diffraction point at $19.2(\theta)$ was attributed to the presence of amylose-lipid complexes (Nwokocha \& Williams 2011).

The starch presented low water absorption capacity (WAC), $1.06 \mathrm{~g}_{\text {water }} / \mathrm{g}_{\text {starch }}( \pm 0.07)$, which might be due to the amylose content. The breadfruit starch presented as liquid at concentrations of $2-4 \%(\mathrm{w} / \mathrm{v})$, viscous at $6-10 \%(\mathrm{w} / \mathrm{v})$ and the lowest concentration of gel formation (LGC) was $12 \%(\mathrm{w} / \mathrm{v})$. In contrast, Adebowale et al. (2006) obtained the lowest gel concentration of $6 \%$.

The starch showed an increase in viscosity in the initial heating phase. The granules began to swell at a temperature of $75.10^{\circ} \mathrm{C}$. The maximum viscosity was $3349.00 \mathrm{cP}$ at a temperature of $78^{\circ} \mathrm{C}$. Posterior cooling led to a decrease in viscosity $(2651.00 \mathrm{cP})$ and after it increased to $5200 \mathrm{cP}$ of viscosity.

The clarity of the starch paste in the first 24 hours of storage was $5.61 \%$, with a decrease in light transmittance to $5.10 \%$ in the next five days of storage, with statistical significance. Syneresis is related to water expulsion during the retrogradation of the starch gel through a strong interaction of amylose and amylopectin chains (Denardin \& Silva, 2009). The amount of starch released (syneresis) in the first $24 \mathrm{~h}$ was $14.77 \%( \pm 0.14)$, decreasing the water release during the storage period, reaching $28.88 \%$ in 360 hours. The breadfruit starch presented low syneresis and could be applied to films, refrigerated or frozen products.

The cherry tomatoes without coating (Control cherry tomatoes) had an initial mass of $8.31 \mathrm{~g}( \pm 0.04)$, a moisture content of $93.89 \%( \pm 0.17)$, water activity of $0.999( \pm 0.01)$, ash of $0.35 \%$ ( \pm 0.02$), \mathrm{pH}$ of 4.13 , titratable total acidity of $0.71 \%$ $( \pm 0.06)$, vitamin C of $16.3 \mathrm{mg}$ ascorbic acid/100 g sample $( \pm 0.09)$ and total soluble solids of $5.5^{\circ} \mathrm{Brix}( \pm 0.03)$. Vieira et al. (2014) found similar results for moisture content of $91.47 \%$, ash of $0.33 \%$, pH of 4.46 for conventional tomatoes, and also found a lower total titratable acidity of $0.44 \%$, higher total soluble solids and $6.95^{\circ}$ Brix.
Coatings tend to decrease the effect of mass loss due to transpiration during the period of the post-harvest handling and storage of fruits (Tumwesigye et al., 2017). The coatings containing glycerol (C1) and sorbitol (C2) showed a reduction in the mass loss when compared to the control (CT), while the coating with mannitol (C3) showed a high mass loss (54\%) (Figure 3a). Moisture and water activity reduced with the increase in storage time. C3 treatment showed the most significant reduction in moisture, thus corroborating the results observed for fruit mass loss due to water loss (Figure 4b).

Titratable acidity, $\mathrm{pH}$ and total soluble solids ( $\left.{ }^{\circ} \mathrm{Brix}\right)$ can be used to evaluate food quality in the post-harvest period due to its influence on processing conditions (Vieira et al., 2014; Tumwesigye et al., 2017). Most of the evaluated fruits were within the ideal range for cherry tomatoes, where the desirable $\mathrm{pH}$ is between 4.5 and 3.7. It was observed that there was an increase in $\mathrm{pH}$ in the studied storage period and that $\mathrm{C} 3$ presented a $\mathrm{pH}$ increase from $4.16( \pm 0.02)$ to $4.84( \pm 0.03)$. The increase in $\mathrm{pH}$ occurs due to the decrease in concentration of organic acids which are used as a substrate for the respiration process, or in the transformation into sugars after maturity (Fagundes et al., 2015). The results found for treatment $\mathrm{C} 3$ indicate an accelerated maturation process when compared to C1 (4.48 \pm 0.01$)$ and C2 $(4.61 \pm 0.01)$. The lower $\mathrm{pH}$ values are directly related to the more acidic taste (Fagundes et al., 2015). Titratable total acidity decreased during the storage period, and C3 presented lower acidity (Figure 4f).

A gradual increase in the concentration of total soluble solids ( ${ }^{\circ}$ Brix) during the storage period (Figure 4e) was observed. However, they were higher in C3 and CT compared to C1 and C2 cherry tomatoes. The increase in total soluble solids during storage is due to the degradation of polysaccharides in the respiratory process of fruits (Chitarra \& Chitarra, 1990). The SST/TA ratio (maturation index, MI) was higher in the $\mathrm{C} 3$ and $\mathrm{CT}$ treatments (18.07 and 14.62, respectively) than in the $\mathrm{C} 1$ and $\mathrm{C} 2$ treatments (10.51 and 9.83, respectively) (Figure 3f). Higher values of SST/AT ratio imply a smooth taste of the fruit due to the sugar and acid combination of the ripening (Ferreira et al., 2004).

C3 and CT presented higher losses of ascorbic acid with storage time (Figure 4h). C1 and C2 showed low loss of ascorbic acid, delaying the metabolic process and consequent degradation of ascorbic acid. Treatments $\mathrm{C} 1$ and $\mathrm{C} 2$ probably act as the best barrier against oxygen permeation.

The tomatoes were sensorially evaluated (Figure 3). C3 did not present good acceptance, being statistically different and received low scores on all evaluated attributes. The fruits showed cracks in the surface and were wilted on the skin. C2 presented no statistical difference $(\mathrm{p}>0.05)$ regarding the general appearance of the fruit between the $1^{\text {st }}$ and $12^{\text {th }}$ day of storage, with a score varying from "moderately liked" to "liked very much". C1 did not differ statistically between the $1^{\text {st }}$ and $9^{\text {th }}$ day. The control showed a decrease in preference from the $3^{\text {rd }}$ day of storage, from the "moderately liked" score to "neither liked nor disliked".

C1 and C2 obtained good acceptance of color and brightness, showing no statistical difference $(\mathrm{p}>0.05)$. C3 presented lower scores regarding color and brightness when compared to other 

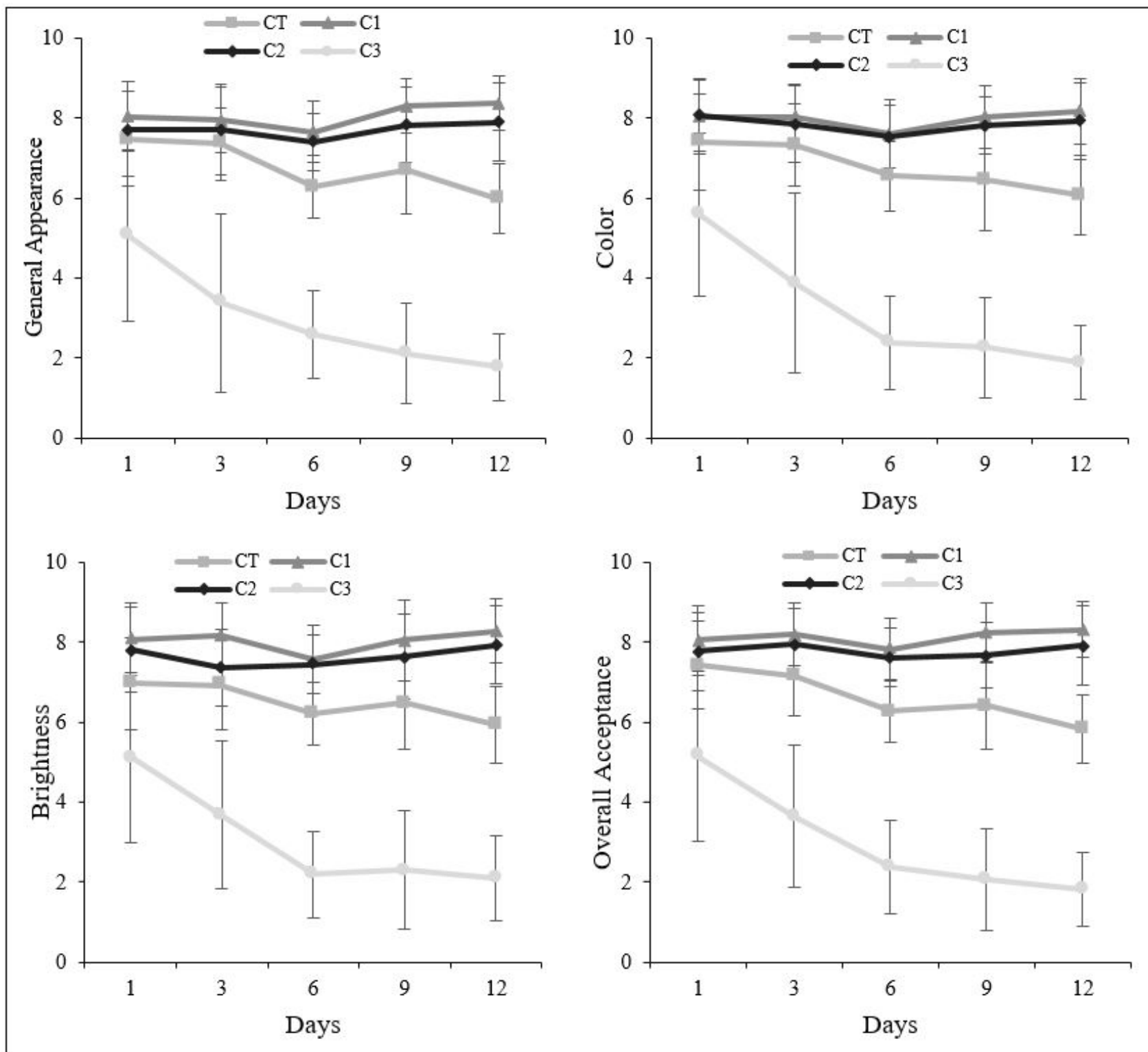

Figure 3. Grades attributed by the judges for each attribute of cherry tomatoes (general appearance, color, brightness and overall acceptance) during storage. Mean \pm standard deviation ( $\mathrm{n}=60$ a day). The means followed by the same letter do not differ statistically from each other by the Tukey test at the $5 \%$ probability level. Lower case are the differences among treatments, upper case are the differences in time.

treatments. Observations made by the judges indicated that fruits from C3 had off-white appearance evidencing the non-efficacy of the plasticizer for the coating of cherry tomatoes. $\mathrm{C} 1$ and $\mathrm{C} 2$ presented better sensory scores for overall acceptance when compared to control, attesting to the efficacy of glycerol and sorbitol coating.

Regarding the intention to buy, $80 \%$ and $68.3 \%$ of judges "would certainly buy" the fruits at the $\mathrm{C} 1$ and $\mathrm{C} 2$ treatment. With storage time, the $\mathrm{C} 1$ and $\mathrm{C} 2$ coated tomatoes maintained their grades regarding the judges' intention to buy, and the control tomatoes lost their preference. Judges indicated that they would not purchase C3 fruits, and the scores ranged from "certainly would not buy" to "possibly would not buy", presenting $86.6 \%$ rejection on the $12^{\text {th }}$ day.
From the CATA analysis of tomatoes coated with breadfruit starch with different plasticizers (Figure 5), it was possible to observe that $\mathrm{C} 1$ and $\mathrm{C} 2$ presented characteristics of bright, uniform, pleasant, and vivid. The control tomatoes were described as not very bright, pale and opaque, and fruits from C3 were classified as exudative, brittle or cracked, unpleasant, with particles, containing holes and fragments, atypical coloring and non-uniform.

The sensorial results corroborate the physical and chemical attributes and suggest that the treatment using mannitol as a plasticizer was not effective in the conditions used in this study. It was observed that coatings with glycerol and sorbitol showed better results and could be indicated as plasticizing agents for the preparation of a starch-based coating from breadfruit. 

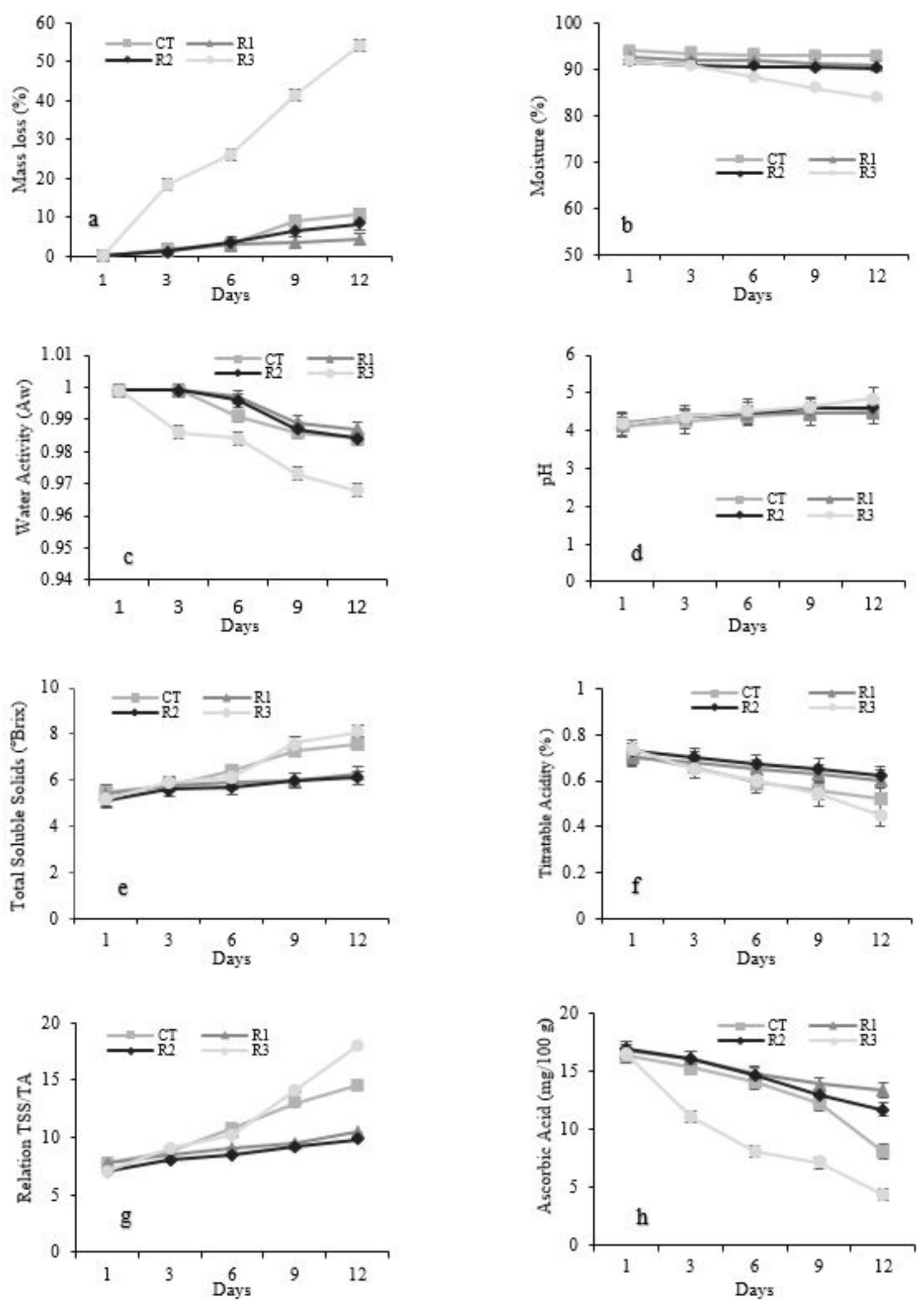

Figure 4. Influence of the starch-based coating from breadfruit with different plasticizers on the shelf-life of cherry tomatoes. (a) mass loss; (b) moisture; (c) water activity; (d) pH; (e) total soluble solids ( ${ }^{\circ} \mathrm{Brix}$ ); (f) titratable acidity; (g) relation TSS/TA; and (h) ascorbic acid from cherry tomatoes stored at $18{ }^{\circ} \mathrm{C}$ during 12 days $\mathrm{CT}=$ control; $\mathrm{R} 1=$ starch with glycerol as plasticizer; $\mathrm{R} 2=$ starch with sorbitol as plasticizer; $\mathrm{R} 3=$ starch with mannitol as plasticizer. 


\section{CA factor map}

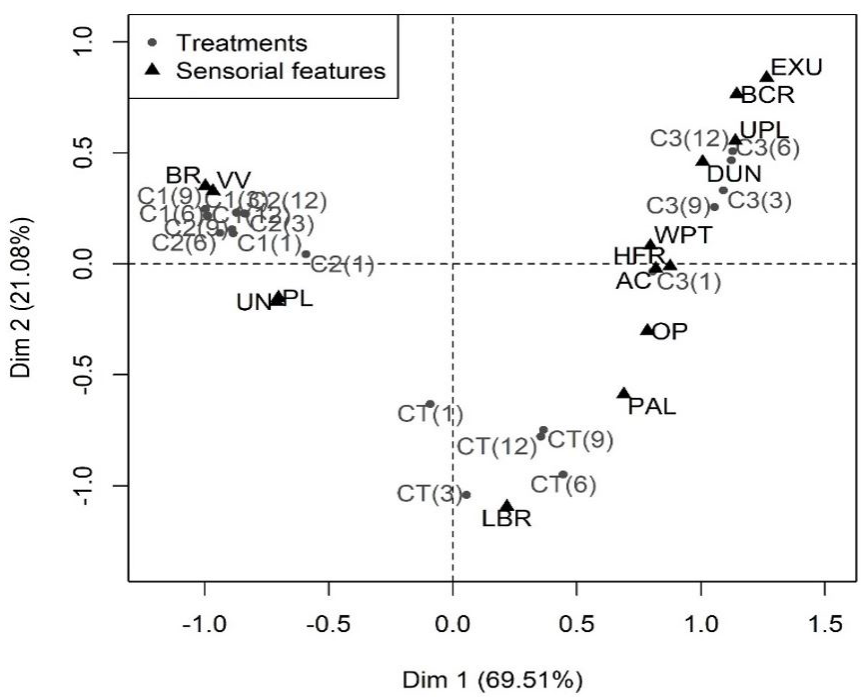

Figure 5. Correspondence analysis of CATA responses: representation of terms sensorial. $\mathrm{BR}=$ brilliant; $\mathrm{LBR}=$ little bright; $\mathrm{OP}=$ opaque; $\mathrm{UN}$ = uniform; HFR = hole and fragments; DUN = non-uniform; $\mathrm{WPT}=$ with particles; $\mathrm{UPL}=$ unpleasant $\mathrm{PL}=$ pleasant $\mathrm{BCR}=$ brittle and crackle; $\mathrm{VV}=$ vivid; $\mathrm{PAL}=$ pale; $\mathrm{AC}=$ atypical coloring; EXU = exudative. Treatments: Control (CT), Coating 1 (C1), Coating 2 (C2) and Coating 3 (C3).

\section{Conclusion}

Breadfruit starch may be an alternative for use in bioproducts, which can be used in coatings with glycerol and sorbitol. Coatings with glycerol and sorbitol in combination with breadfruit starch delayed the maturation process of the cherry tomato. Sensory results confirm that glycerol or sorbitol coatings are indicated for preparation of starch-based breadfruit coating, improving the post-harvest quality of cherry tomatoes with a higher acceptance and purchase probability than fruits without coating. Thus, coatings based on breadfruit starch can serve as subsidies for the development of new technologies in the food industry.

\section{References}

Adebowale, K. O., Afolabi, T. A., \& Olu-owolabi, B. I. (2006). Functional, physicochemical and retrogradation properties of sword bean (Canavalia gladiata) acetylated and oxidized starches. Carbohydrate Polymers, 10(1), 93-101. http://dx.doi.org/10.1016/j.carbpol.2005.12.032.

Adebowale, K. O., Olu-Owolabi, B. I., Olawumi, E. K., \& Lawal, O. S. (2005). Functional properties of native, physically and chemically modified breadfruit (Artocarpus artilis) starch. Industrial Crops and Products, 21(3), 343-351. http://dx.doi.org/10.1016/j.indcrop.2004.05.002.

Akanbi, O., Nazamid, S., \& Adebowale, A. A. (2009). Functional and pasting properties of a tropical breadfruit (Artocarpus altilis) starch from Ile-Ife, Osun State, Nigeria. International Food Research Journal, 16, 151-157. Retrieved from https://www.researchgate.net/ publication/275833201

Ali, A., Maqbool, M., Alderson, P. G., \& Zahid, N. (2013). Effect of gum arabic as an edible coating on antioxidant capacity of tomato (Solanum lycopersicum L.) fruit during storage. Postharvest
Biology and Technology, 76, 119-124. http://dx.doi.org/10.1016/j. postharvbio.2012.09.011.

Ali, A., Maqbool, M., Ramachandran, S., \& Alderson, P. G. (2010). Gum arabic as a novel edible coating for enhancing shelf-life and improving postharvest quality of tomato (Solanum lycopersicum L.) fruit. Postharvest Biology and Technology, 58(1), 42-47. http:// dx.doi.org/10.1016/j.postharvbio.2010.05.005.

American Association Cereal Chemists - AACC. (2010). Approved methods of analysis (11th ed.). Saint Paul: AACC. Retrieved from http://methods.aaccnet.org/toc.aspx

Ares, G., Deliza, R., Barreiro, C., Giménez, A., \& Gambarro, A. (2010). Application of a check-all-that-apply questions to the development of chocolate milk desserts. Journal of Sensory Studies, 25, 67-86. http://dx.doi.org/10.1111/j.1745-459X.2010.00290.x.

Ares, G., Etchemendy, R., Antúnez, L., Vidal, L., Giménez, A., \& Jaeger, S. (2014). Visual attention by consumers to check-all-that-apply questions: insights to 4 support methodological development. Food Quality and Preference, 32, 210-220. http://dx.doi.org/10.1016/j. foodqual.2013.10.006.

Association of Official Analytical Chemists - AOAC. (2005). Official methods of analysis of Association of Official Chemists (13th ed.). Washington: AOAC.

Badawy, M. E. I., \& Rabea, E. I. (2009). Potential of the biopolymer chitosan with different molecular weights to control postharvest gray mold of tomato fruit. Postharvest Biology and Technology, 51(1), 110-117. http://dx.doi.org/10.1016/j.postharvbio.2008.05.018.

Beckles, D. M. (2012). Factors affecting the postharvest soluble solids and sugar content of tomato (Solanum lycopersicum L.) fruit. Postharvest Biology and Technology, 63(1), 129-140. http://dx.doi.org/10.1016/j. postharvbio.2011.05.016.

Beuchat, L. R. (1977). Functional and electrophoretic characteristic of succunylated peanut flour proteins. Journal Agriculture Chemistry, 25(2), 258-261. http://dx.doi.org/10.1021/jf60210a044.

Cazón, P., Velazquez, G., Ramírez, J. A., \& Vázquez, M. (2017). Polysaccharide-based films and coatings for food packaging: a review. Food Hydrocolloids, 68, 136-148. http://dx.doi.org/10.1016/j. foodhyd.2016.09.009.

Chiang, B. H., Chu, W. C., \& Chu, C. L. (1987). A pilot scale study for banana starch production. Stärke, 39(1), 5-8. http://dx.doi. org/10.1002/star.19870390103.

Chitarra, M. I. F., \& Chitarra, A. B. (1990). Pós-colheita de frutos e hortaliças. Lavras: Escola Superior de Agricultura de Lavras.

Denardin, C. C., \& Silva, L. P. (2009). Estrutura dos grânulos de amido e sua relação com propriedades físico-químicas. Ciência Rural, 39(3), 945-954. http://dx.doi.org/10.1590/S0103-84782009005000003.

Dutcosky, S. D. (2013). Análise sensorial de alimentos (4. ed.) Curitiba: Champagnat.

Fagundes, C., Moraes, K., Pérez-gago, M. B., Palou, L., Maraschin, M., \& Monteiro, A. R. (2015). Effect of active modified atmosphere and cold storage on the postharvest quality of cherry tomatoes. Postharvest Biology and Technology, 109, 73-81. http://dx.doi.org/10.1016/j. postharvbio.2015.05.017.

Fagundes, C., Palou, L., Monteiro, A. R., \& Pérez-Gago, M. B. (2014). Effect of antifungal hydroxypropyl methylcellulose-beeswax edible coatings on gray mold development and quality attributes of coldstored cherry tomato fruit. Postharvest Biology and Technology, 92, 1-8. http://dx.doi.org/10.1016/j.postharvbio.2014.01.006.

Falcão-Rodrigues, M. M., Moldão-Martins, M., \& Beirão-da-Costa, M. L. (2007). DSC as a tool to assess physiological evolution of apples 
preserved by edible coatings. Food Chemistry, 102(2), 475-480. http://dx.doi.org/10.1016/j.foodchem.2006.05.016.

Ferreira, S. M. R., Freitas, R. J. S., \& Lazzari, E. N. (2004). Padrão de identidade e qualidade do tomate (Lycopersicon esculentum Mill.) de mesa. Ciência Rural, 34(1), 329-335. http://dx.doi.org/10.1590/ S0103-84782004000100054.

Labanca, R. A., Silva, C. M. G., \& Glória, M. B. A. (1999). Starch levels in refrigerated and frozen chicken based meat products. Brazilian Archives of Biology and Technology, 42(2), 1-6. http://dx.doi. org/10.1590/S1516-89131999000200008.

Lawal, O. S., \& Adebowale, K. O. (2005). Physicochemical characteristics and termal properties of chemically modified jack bean (Canavalia ensiformes) starch. Carbohydrate Polymers, 60(3), 331-341. http:// dx.doi.org/10.1016/j.carbpol.2005.01.011.

Martínez, C., Cuevas, F., \& Medina, L. M. (1989). Evaluación de lacalidad culinaria y molineradel arroz: guia de estúdio (6. ed.). Cali: Centro Internacional de Agricultura Tropical.

Nacitas Latchoumia, J., Adenet, S., Aurore, G., Rochefort, K., Buléon, A., \& Fahrasmane, L. (2014). Composition and growth of seedless breadfruit Artocarpus altilis naturalized in the Caribbean. Scientia Horticulturae, 175, 187-192. http://dx.doi.org/10.1016/j. scienta.2014.05.036.

Nawab, A., Alam, F., \& Hasnain, A. (2017). Mango kernel starch as a novel edible coating for enhancing shelf- life of tomato (Solanum lycopersicum) fruit. International Journal of Biological Macromolecules, 103, 581-586. http://dx.doi.org/10.1016/j.ijbiomac.2017.05.057. PMid:28522390.

Nwokocha, L. M., \& Williams, P. A. (2011). Comparative study of physicochemical properties of breadfruit (Artocarpus altilis) and white yam starches. Carbohydrate Polymers, 85(2), 294-302. http:// dx.doi.org/10.1016/j.carbpol.2011.01.050.

R Core Team. (2014). R: a language and environment for statistical computing. Vienna: R Foundation for Statistical Computing. Retrieved from http://www.R-project.org/

Ricón, A. M., \& Padilla, F. C. (2004). Physicochemical properties of breadfruit (Artocarpus altilis) starch from Margarita island, Venezuela. Archivos Latinoamericanos de Nutricion, 54(4), 449-456. PMid:15969272.

Rowney, M. K., Hickey, M. W., Roupas, P., \& Everett, D. W. (2003). The effect of homogenization and milk fat fractions on the functionality of mozzarella cheese. Journal of Dairy Science, 86(3), 712-718. http:// dx.doi.org/10.3168/jds.S0022-0302(03)73651-0. PMid:12703605.

Singh, N., Singh Sandhu, K., \& Kaur, M. (2004). Characterization of starches separated from Indian chickpea (Cicer arietinum L.) cultivars. Journal of Food Engineering, 63(4), 441-449. http://dx.doi. org/10.1016/j.jfoodeng.2003.09.003.

Tan, X., Li, X., Chen, L., Xie, F., Li, L., \& Huang, J. (2017). Effect of heatmoisture treatment on multi-scale structures and physicochemical properties of breadfruit starch. Carbohydrate Polymers, 161, 286-294. http://dx.doi.org/10.1016/j.carbpol.2017.01.029. PMid:28189241.

Tumaalii, F., \& Wootton, M. (1988). Properties of starches isolated from Western Samoan breadfruit using a traditional method. Stärke, 40(1), S7-S10. http://dx.doi.org/10.1002/star.19880400103.

Tumwesigye, K. S., Sousa, A. R., Oliveira, J. C., \& Sousa-Gallagher, M. J. (2017). Evaluation of novel bitter cassava film for equilibrium modified atmosphere packaging of cherry tomatões. Food Packaging and ShelfLife, 13, 1-14. http://dx.doi.org/10.1016/j.fpsl.2017.04.007.

Turi, C. E., Liu, Y., Ragone, D., \& Murch, S. J. (2015). Breadfruit (Artocarpus altilis and hybrids): A traditional crop with the potential to prevent hunger and mitigate diabetes in Oceania. Trends in Food Science \& Technology, 45(2), 264-272. http://dx.doi.org/10.1016/j. tifs.2015.07.014.

Universidade Federal de Campina Grande - UFCG. (2014). Assistat 7.6 Beta: assistência estatística. Campina Grande: DEAG-CTRM.

Vieira, D. A. P., Cardoso, K. C. R., Dourado, K. K. F., Caliari, M., \& Soares, M. S., Jr. (2014). Qualidade física e química de mini-tomates Sweet Grape produzidos em cultivo orgânico e convencional. Revista Verde de Agroecologia e Desenvolvimento Sustentável, 9, 100-108. Retrieved from http://www.gvaa.com.br/revista/index.php/RVADS/ article/view/2672

Wang, X., Chen, L., Li, X., Xie, F., Liu, H., \& Yu, L. (2011). Thermal and rheological properties of breadfruit starch. Journal of Food Science, 76(1), 55-61. http://dx.doi.org/10.1111/j.1750-3841.2010.01888.x. PMid:21535676.

Wootton, M., \& Tumaalii, F. (1984). Composition of flours from Samoan breadfruit. Journal of Food Science, 49(5), 1396-1397. http://dx.doi. org/10.1111/j.1365-2621.1984.tb15000.x.

Wu, S., Lu, M., \& Wang, S. (2016). Effect of oligosaccharides derived from laminaria japonica-incorporated pullulan coatings on preservation of cherry tomatoes. Food Chemistry, 199, 296-300. http://dx.doi. org/10.1016/j.foodchem.2015.12.029. PMid:26775974. 